\title{
Above-Optimum Temperature-Induced Differential Photosynthetic and Roots Morphometric Responses in Two Contrasting Rice Genotypes
}

\author{
Diogo da Silva Moura ${ }^{1}$, Ítalo Lucas de Moraes ${ }^{1}$, Rodrigo da Silva Armesto ${ }^{1}$, Rafael Silva da Silva ${ }^{1}$, Fernanda \\ Reolon $^{1}$, Junior Borela ${ }^{1}$, Paulo Ricardo Reis Fagundes ${ }^{2}$, Giovani Greigh de Brito ${ }^{2}$ and Sidnei Deuner ${ }^{1}$ \\ 1. Institute of Biology, Department of Botany, Federal University of Pelotas (UFPel), Capão do Leão 96010-900, RS, Brazil \\ 2. EMBRAPA Temperate Climate, Brazilian Agricultural Research Corporation, Pelotas 96010-971, RS, Brazil
}

\begin{abstract}
Temperature thresholds during the rice (Oryza sativa L.) cycle development have been reported to affect plant metabolism. Therefore, this study aimed to evaluate the effects of the above-optimal temperature on photosynthetic and morphometric parameters in two contrasting irrigated rice genotypes (BRS Querência — sensitive and Nagina 22 (N22) - tolerant). Plants of both genotypes were grown in rhizotrons and always maintained under two temperature conditions: Out-under environmental temperature conditions, and $\mathrm{In}$-rhizotrons inside a plastic structure, which increased the temperature about $3{ }^{\circ} \mathrm{C}$ to $5{ }^{\circ} \mathrm{C}$ above the external one. In the genotype $\mathrm{N} 22$, there was an increase (twofold higher) in $\mathrm{CO}_{2}$ assimilation in plants cultivated under elevated temperature (In). In BRS Querência, the stomatal conductance $\left(g_{s}\right)$ and transpiration rate $(E)$ decreased upon high temperature. The rise in the temperature also negatively impacted in the modulated fluorescence parameters in both genotypes. Increases in root dry weight $(R D W)$ and shoot dry weight $(S D W)$ were also observed in the genotype N22 when compared to BRS Querência upon temperature rise. In general, the N22 genotype showed greater response to the above-optimal temperature due to its intrinsic thermotolerance traits over BRS Querência. Thus, N22 appeared as a potential donor of heat tolerance genes aiming to obtain new cultivar to face current global warming.
\end{abstract}

Key words: Oryza sativa L., heat, thermotolerance, photosynthesis, root system.

\section{Introduction}

Rice is the most important food crop cultivated worldwide due to its growth adaptability in a multitude of environments and has been considered a staple food for human consumption [1]. However, as an increase in growth population is expected [2], food production, such as annual cereal production, must increase over the next years [3]. To reach this demand, rice farmers will need to produce about 8-10 million tons more paddy per year without area expansion (productivity of rice per unit of land), requiring annual yield increase of about $1.2 \%-1.5 \%$ [1]. As rice yield increases have slowed about $0.8 \%$ in the last decades,

Corresponding author: Sidnei Deuner, Ph.D., research fields: plant nutrition and metabolism. mainly due to the negative impacts of increase in the temperature, a consequence of global warming, especially increases in night-time temperatures [4-6]. Thus, efforts are necessary to understand how above-optimal temperature affects critical cycle stages of rice, aiming to construct plants ideotypes to supply the global food requirement.

In this sense, forecasts estimated the rise in the average temperature from $2{ }^{\circ} \mathrm{C}$ to $5.4{ }^{\circ} \mathrm{C}$, up to 2100 [6], with optimistic increases in the temperature in Brazil, up to $3.8^{\circ} \mathrm{C}$ [7]. In the south of Brazil (mostly in the Rio Grande do Sul state), where the rice production reached $81.6 \%$ of the national productivity [8], it has been reported that an increase in the minimum average temperature (approximately $2{ }^{\circ} \mathrm{C}$ ) in the summer season (Jan.-Mar.) may negatively 
impact on yield components and, consequently on grain yield and quality when exceeding the temperature threshold suitable for plant development.

Temperature rises can significantly influence photosynthetic mechanisms, such as increases in $\mathrm{CO}_{2}$ assimilation via RuBisCO enzyme and ribulose 1.5-bisphosphate regeneration (RuBP) through Calvin-Benson cycle [9]. So far, studies of the authors' group have reported that increases in the temperature average above the optimal one lead to a decrease in $\mathrm{CO}_{2}$ assimilation and consequently losses in rice productivity [10]. However, the temperature was above the optimal threshold for rice flowering [11] and, for most plant species, vegetative development usually has a higher optimum temperature than for reproductive development [12].

Rates of photosynthesis and respiration increase with an increase in temperature until a threshold at which maximum photosynthesis level is achieved. Generally, it is around $22-24^{\circ} \mathrm{C}$ and remains that way, up to $30-35{ }^{\circ} \mathrm{C}$ [13], with biomass increasing up to $33^{\circ} \mathrm{C}$ in rice [14]. The decline was observed between $40{ }^{\circ} \mathrm{C}$ and $43{ }^{\circ} \mathrm{C}$, although assimilation rates at these temperatures remained positive, whereas steady-state fluorescence yield declined up to $41{ }^{\circ} \mathrm{C}$ and then increased moderately above it, implying drastically reduced effective quantum yields of photosystem II (PSII- $\Phi_{\text {PSII }}$ ) [13].

The extent to which elevated temperature occurs in specific climatic zones is a complex issue. Plants can be damaged in diverse ways by either high day or high night temperatures and by either high air or high soil temperatures. Also, crop species and cultivars differ in their sensitivity to high temperatures, according to phenological stages $[4,11,15,16]$, which have been reported as plant-genotype specific [17], and to temperature thresholds [16].

In rice, when temperature increases from a base of $8{ }^{\circ} \mathrm{C}$ to $36-40{ }^{\circ} \mathrm{C}$ (the thermal threshold of survival), there is an increase in leaf appearance rate [18], biomass increases until temperatures reach $33^{\circ} \mathrm{C}$ [14].
However, grain formation and yield are maximum at the optimum temperature of $25^{\circ} \mathrm{C}$ [18]. Cheng et al. [19] found that high night temperatures increased living leaf $\mathrm{N}$ concentration and leaf area (LA), and caused higher photosynthetic capacity during the last stage of growth. Carbon assimilation also increases with higher night temperatures, and however, loss of carbon increases due to respiration.

The effect of elevated temperature on plant growth and development has not been extensively studied in rice, especially at early stages of development. As vegetative stage precedes reproductive one, increases in temperature above optimal one may lead to a progressive failure to produce filled grains caused by reduced pollen viability and pollen production [20]. Besides, the contrasting productivity of rice genotypes may be due to the differential in the dynamic assimilation partitioning within plants during the growth and development [21]. Therefore, the aim of this study was to evaluate photosynthetic and morphometric responses of two contrasting irrigated rice genotypes subjected to an above-optimal temperature at initial stages of development.

\section{Materials and Methods}

\subsection{Plant Materials and Growth Conditions}

The experiment was carried out in the summer season (Dec. 15 to Jan. 16) with two irrigated rice genotypes contrasting to elevated temperature (BRS Querência—sensitive and Nagina 22 (N22) - tolerant) [22]. The genotypes were previously selected based on studies of the authors' group (data not published).

Plants were grown in rhizotrons $(120 \mathrm{~cm} \times 35 \mathrm{~cm})$ from seeds, as shown in Fig. 1, containing soil (planosol hydromorphic eutrophic solodic) as substrate. After germination, only one plant was kept per rhizotron. To allow root growth within the rhizotron, it inclined $45^{\circ}$ using pieces of wood as support. Both genotypes were exposed to two temperature gradients: Out - plants were grown in rhizotron under natural temperature conditions; 


\section{Above-Optimum Temperature-Induced Differential Photosynthetic and Roots Morphometric Responses in Two Contrasting Rice Genotypes}

In-plants were grown in rhizotron inside a structure made of plastic (similar to a greenhouse) as shown in Fig. 1, which increased the temperature $3-5^{\circ} \mathrm{C}$ during the day and $1-2{ }^{\circ} \mathrm{C}$ during the night, compared to plants grown under normal temperature conditions (external temperatures).

Soil moisture was measured daily after the irrigation of the plants. Only one plant was kept in each rhizotron. Temperature conditions (In and Out) were monitored through sensors and were shown in Fig. 2.

\subsection{Gas Exchange Analysis}

Gas exchange and modulated fluorescence were

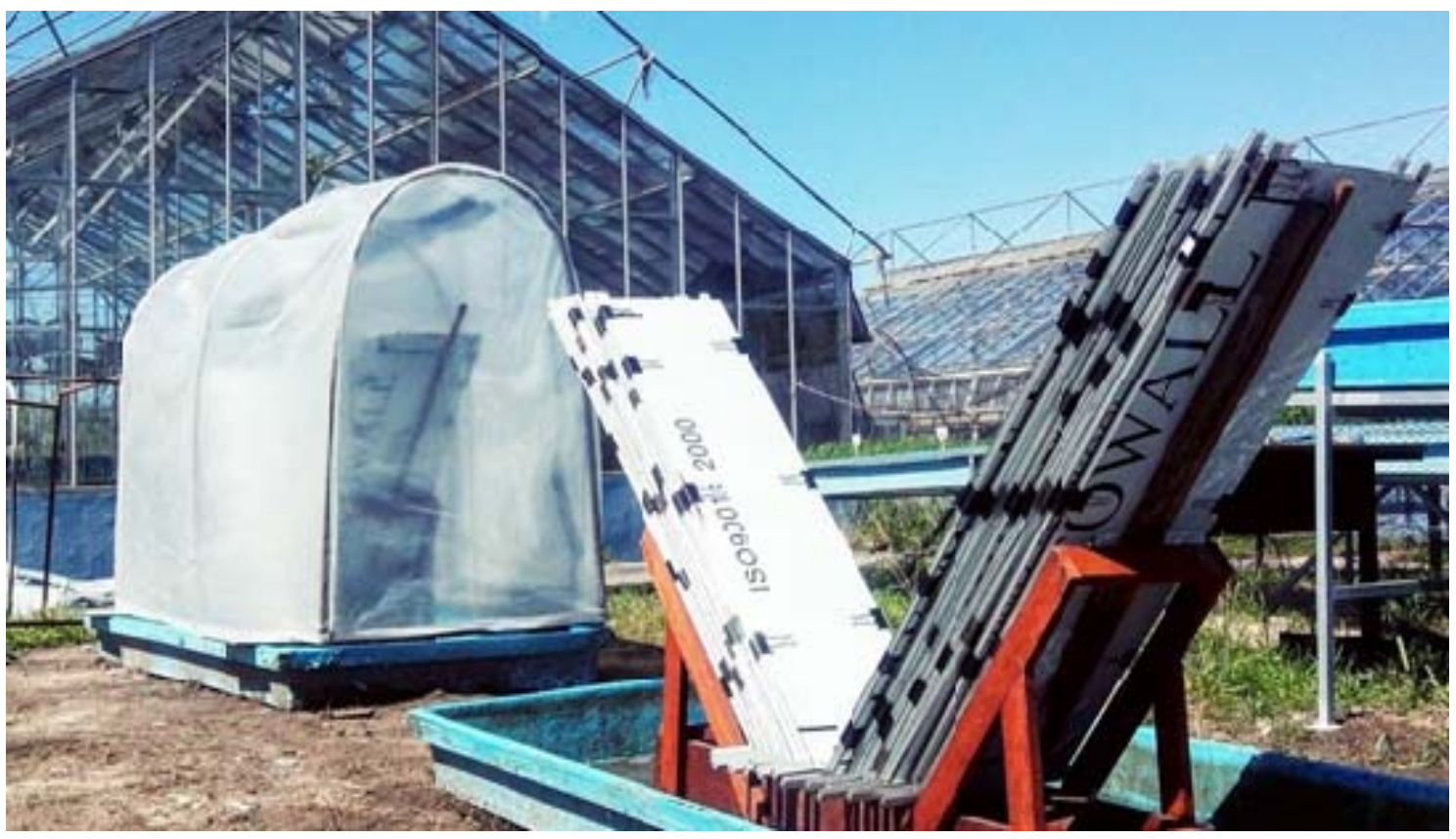

Fig. 1 Cultivation of irrigated rice genotypes in rhizotrons: In (left) and Out (right).

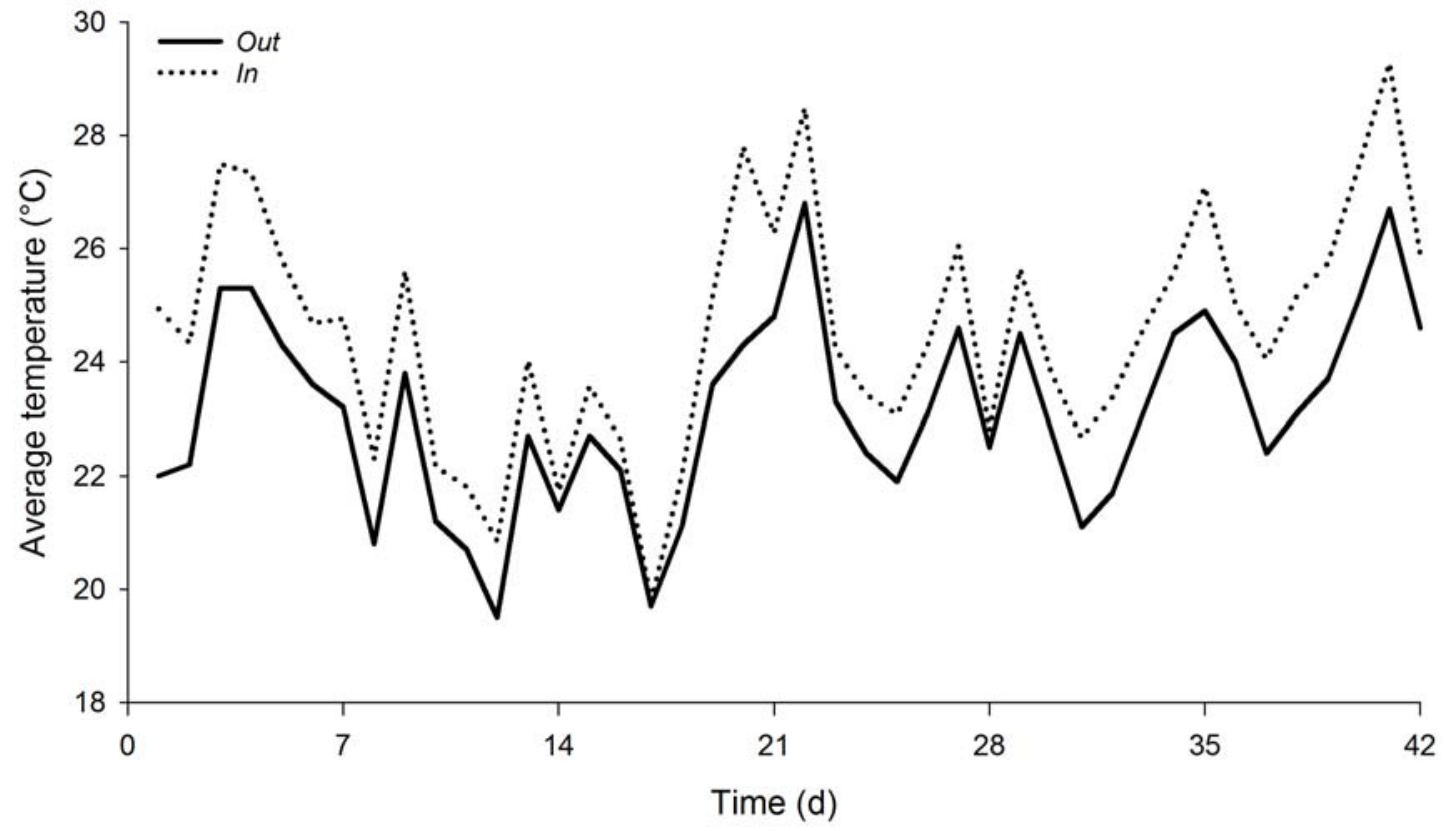

Fig. 2 Average temperatures of the environment (Out) and inside of the plastic structure (In) during the time course of the experiment. 
measured in plants with $42 \mathrm{~d}$ after emergence by using a portable infrared $\mathrm{CO}_{2}$ analyser (model LI-6400XT, LI-COR, Inc., Lincoln, NE, USA). The measurements were taken between 09:00 am and 11:00 am with an in-chamber $\mathrm{CO}_{2}$ concentration of $400 \mu \mathrm{mol} / \mathrm{mol}$ and a photon flow density of $900 \mu \mathrm{mol}$ photons $/ \mathrm{m}^{2} / \mathrm{s}$, using the light source LI-COR attached to the measuring chamber. Net assimilation rate $(A)$, stomatal conductance $\left(g_{s}\right)$ and transpiration rate $(E)$ were measured.

\subsection{Modulated Fluorescence Analysis}

Modulated chlorophyll $a$ fluorescence of dark-adapted leaf of plants was measured using a portable fluorometer (model PAM-2500 from Heinz Walz GmbH, Effeltrich, Germany). Leaves were kept in dark for at least $40 \mathrm{~min}$ and the fluorescence was induced by one saturating flash pulse with $7,000 \mu \mathrm{mol}$ photons $/ \mathrm{m}^{2} / \mathrm{s}$. Maximum effective photochemical quantum yield of PSII $(F v / F m)$, relative electron transport rate $(E T R)$, the coefficient of photochemical fluorescence quenching $(q P)$ and effective photochemical quantum yield of PSII $(Y(I I))$ were measured.

\subsection{Morphometric Analysis}

Root morphometric analysis was taken by photographic camera and image analyser software (WinRHIZO Pro 2013), to measure root length ( $R L)$ and root volume $(R V)$ with 7, 14, 21, 28, 35 and $42 \mathrm{~d}$ after plant emergence. In addition, after $42 \mathrm{~d}$ of plant emergence, LA was estimated with leaf area meter (model LI-3000, LI-COR), and root dry weight (RDW) and shoot dry weight $(S D W)$ were quantified after drying the fresh tissues in an oven at $60^{\circ} \mathrm{C}$.

\subsection{Statistical Analysis}

Each treatment consisted of three replicates and each replicate consisted of one rhizotron containing one plant in a fully randomized design. The data were previously analysed for homoscedasticity (Hartley's test) and normality (Shapiro-Wilk's test) and transformed when necessary. Afterwards, the data were analysed by analysis of variance (ANOVA). When $F$ was significant, the treatment means for each genotype were compared by the Student-Newman-Keuls test or analysis of regression $(p \leq 0.05)$.

\section{Results and Discussion}

\subsection{Photosynthetic Responses of Rice to} Above-Optimal Temperature

The above-optimal temperature effects on photosynthetic parameters of two irrigated rice genotypes were shown in Figs. 3 and 4. Regarding gas exchange analysis (Fig. 3) in plants cultivated in rhizotrons, $A$ increased in plants of N22 genotype about twofold higher when cultivated inside a plastic structure (In-elevated temperature) in comparison to N22 plants under normal temperature conditions (Out-environmental temperature), while no differences in $\mathrm{CO}_{2}$ assimilation were observed in BRS Querência (Fig. 3a).

Photosynthesis has been reported as highly sensitive to heat stress. The optimal temperature for $\mathrm{CO}_{2}$ assimilation ranges from $20{ }^{\circ} \mathrm{C}$ to $35{ }^{\circ} \mathrm{C}$ [13], with increases from the minimum to the maximum temperature threshold. Although plants present a considerable amplitude in optimal photosynthesis temperature, inhibition of photosynthesis normally occurs when the temperature increases above $35{ }^{\circ} \mathrm{C}$ $[23,24]$, due to inhibition of activity of RuBisCO activase and concomitant reduction of $\mathrm{RuBisCO}$ activity [25], or to limiting supply of NADPH and ribulose bisphosphate [26] reflecting the loss of thylakoid $\mathrm{pH}$ gradient [27]. As the temperature threshold for rice in the experiment did not reach the threshold, there was an increase in photosynthesis of $\mathrm{N} 22$, which was also reported in tolerant rice genotypes by Scarfaro et al. [9], in a similar experiment carried out in this study under modified environment (In). 

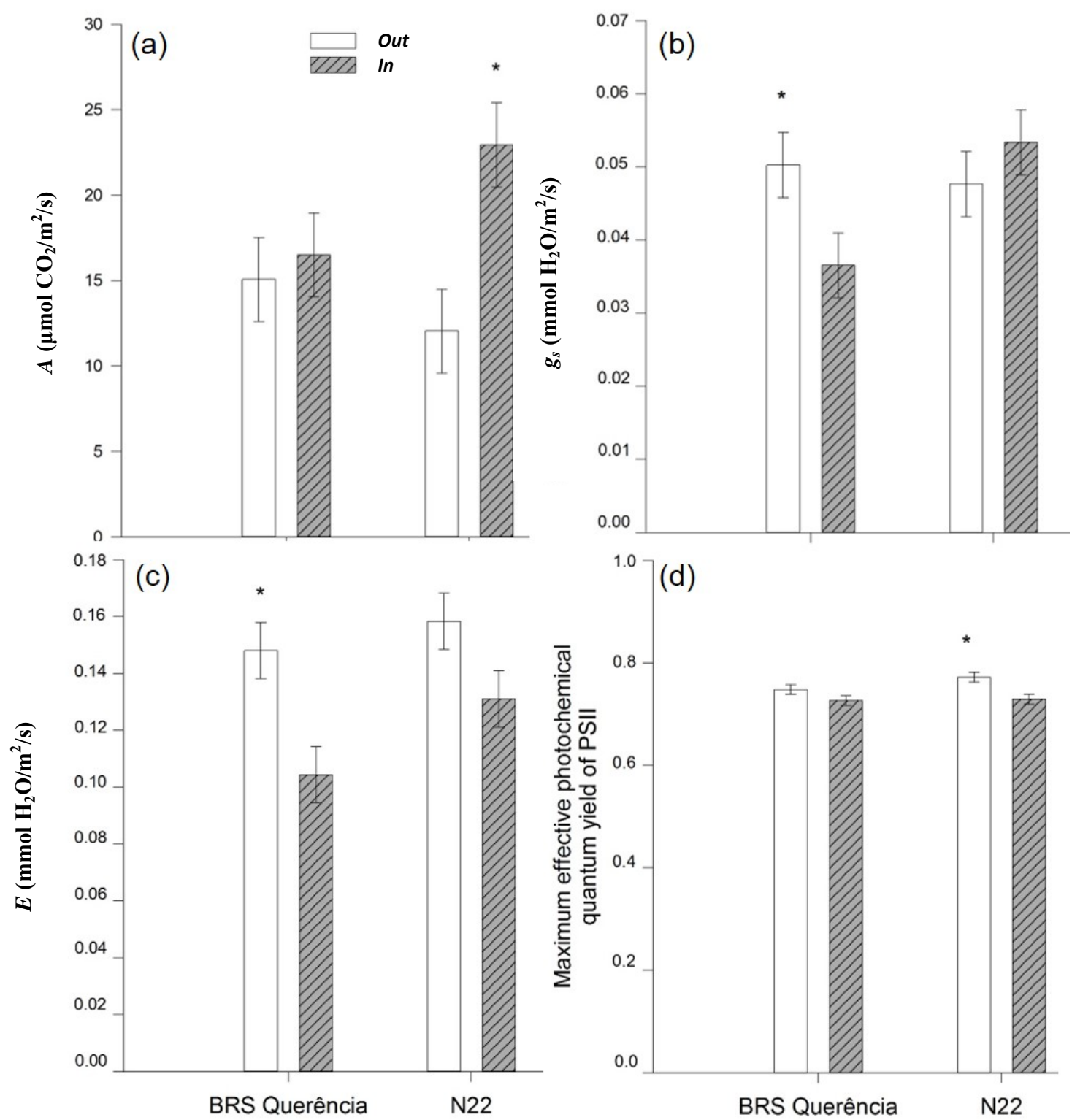

Fig. 3 Photosynthetic responses to above-optimal temperature in two irrigated rice genotypes (BRS Querência and N22).

$A$-net assimilation rate (a), $g_{s}$-stomatal conductance (b), $E$ - transpiration rate (c) and maximum effective photochemical quantum yield of PSII-Fv/Fm (d).

"In"- plants growing in rhizotrons under plastic protection; "Out"- plants growing in rhizotrons under environmental temperature conditions.

An asterisk $(*)$ indicates significant difference by Student's test $(p \leq 0.05)$ between treatments (In and Out) for each genotype.

Values represent the mean $\pm \operatorname{SE}(n=3)$.

In an opposite way, there was a significant reduction (approximately 30\%) in both $g_{s}$ (Fig. 3b) and $E$ (Fig. 3c) in plants of BRS Querência kept in the treatment In compared to plants in Out. Differently, plants of N22 tolerant to elevated temperature did not show alterations in $g_{s}$ and $E$ in response to above-optimal temperature. Leakey et al. [28] and Poons and Welschen [29], reported that the reduction in these parameters was temperature-dependent and can be modulated by genetic traits.

Studies showed that sensitive rice cultivars decreased the $g_{s}$ about $20 \%-50 \%$ upon elevated temperature 
$\left(40{ }^{\circ} \mathrm{C}\right)$, and it varies according to the phenological development stage of plants, being the reproductive one the most affected [30]. Maintaining $g_{s}$ functioning is highly important to reduce leaf temperature some degrees below the air temperature under heat conditions through transpiration [31]. As environments with temperature above the optimal one induces stomatal closure and consequently reduction in $E$, the capacity of maintaining transpiration rates as in plants of N22 may be related to thermotolerance mechanisms, which can keep the photosynthetic process working or even increase it, differently from plants of BRS Querência that showed decreases in $g_{s}$ and $E$.

Optimal temperature for net photosynthesis at current ambient $\mathrm{CO}_{2}$ concentrations is around $30^{\circ} \mathrm{C}$ or slightly above, whereas the optimum temperature for photosynthetic electron transport is typically $5-15{ }^{\circ} \mathrm{C}$ higher [32]. As shown in Fig. 3d, the maximum effective photochemical quantum yield of PSII $(\mathrm{Fv} / \mathrm{Fm})$ reduced in plants of $\mathrm{N} 22$ upon elevated temperature (In) in about $6 \%$, while plants of BRS Querência did not decrease $\mathrm{Fv} / \mathrm{Fm}$ in In compared to plants kept in Out.

Similarly to $F v / F m$, the ETR also reduced (29\%) in plants of N22 under high temperature (In) compared to plants in Out, while plants of BRS Querência did not show difference between the treatments (Fig. 4a).

As shown in the study, the temperature $I n$ increased A (Fig. 3a). On the other hand, the rate of electron transport determined from modulated fluorescence decreased (Fig. 4a). Although impaired electron transport has been already demonstrated under moderate heat stress conditions, slightly exceeding the optimum temperatures [27], photosynthesis rates generally rapidly recover from mild heat stress [13].

The rate of PSII electron transport in leaves is strongly linked to the rate of $\mathrm{CO}_{2}$ fixation, however, part of the electrons from PSII is partitioned to photorespiration and other processes [33]. Thus, the finding that leaves showed the maximum rates of PSII electron in BRS Querência and N22 in Out conditions
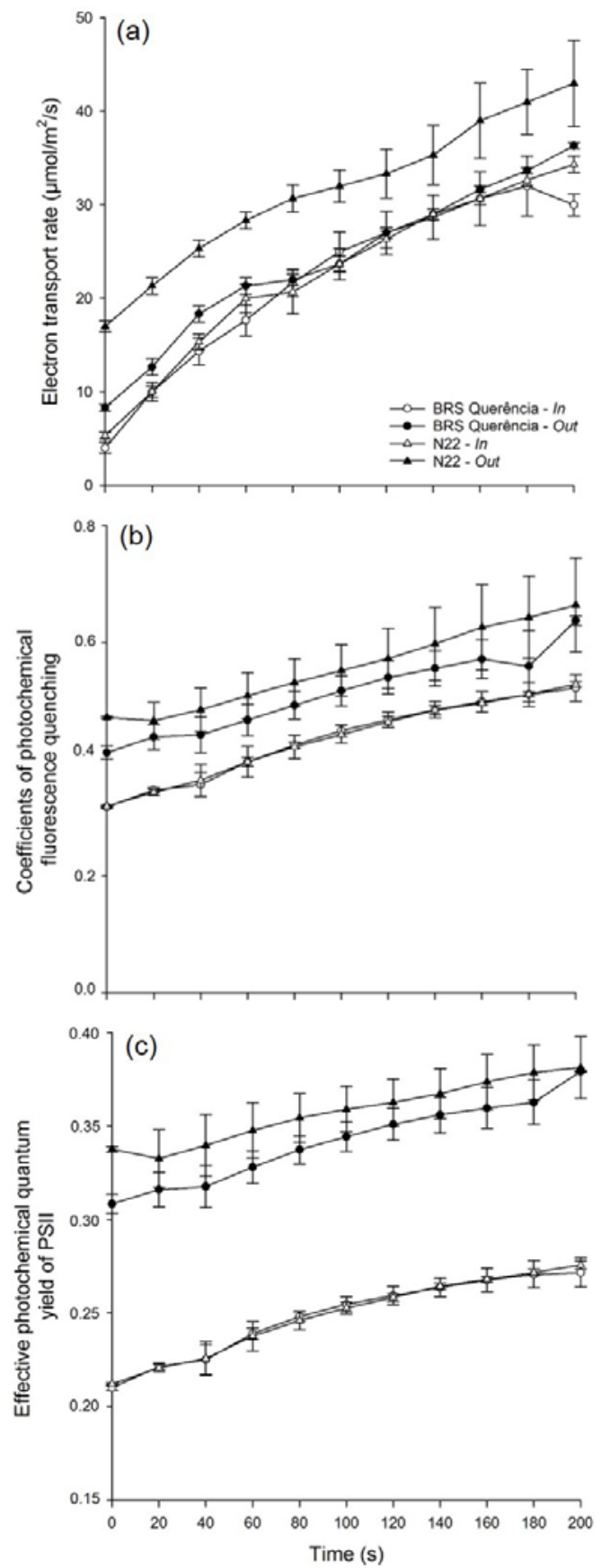

Fig. 4 Modulated chlorophyll $a$ fluorescence to above-optimal temperature in two irrigated rice genotypes (BRS Querência and N22).

Electron transport rate-ETR (a), coefficient of photochemical fluorescence quenching- $q P$ (b), effective photochemical quantum yield of PSII-Y(II) (c).

"In"-plants growing in rhizotrons under plastic protection; "Out"-plants growing in rhizotrons under environmental temperature conditions.

Values represent the mean $\pm \mathrm{SE}(n=3)$. 

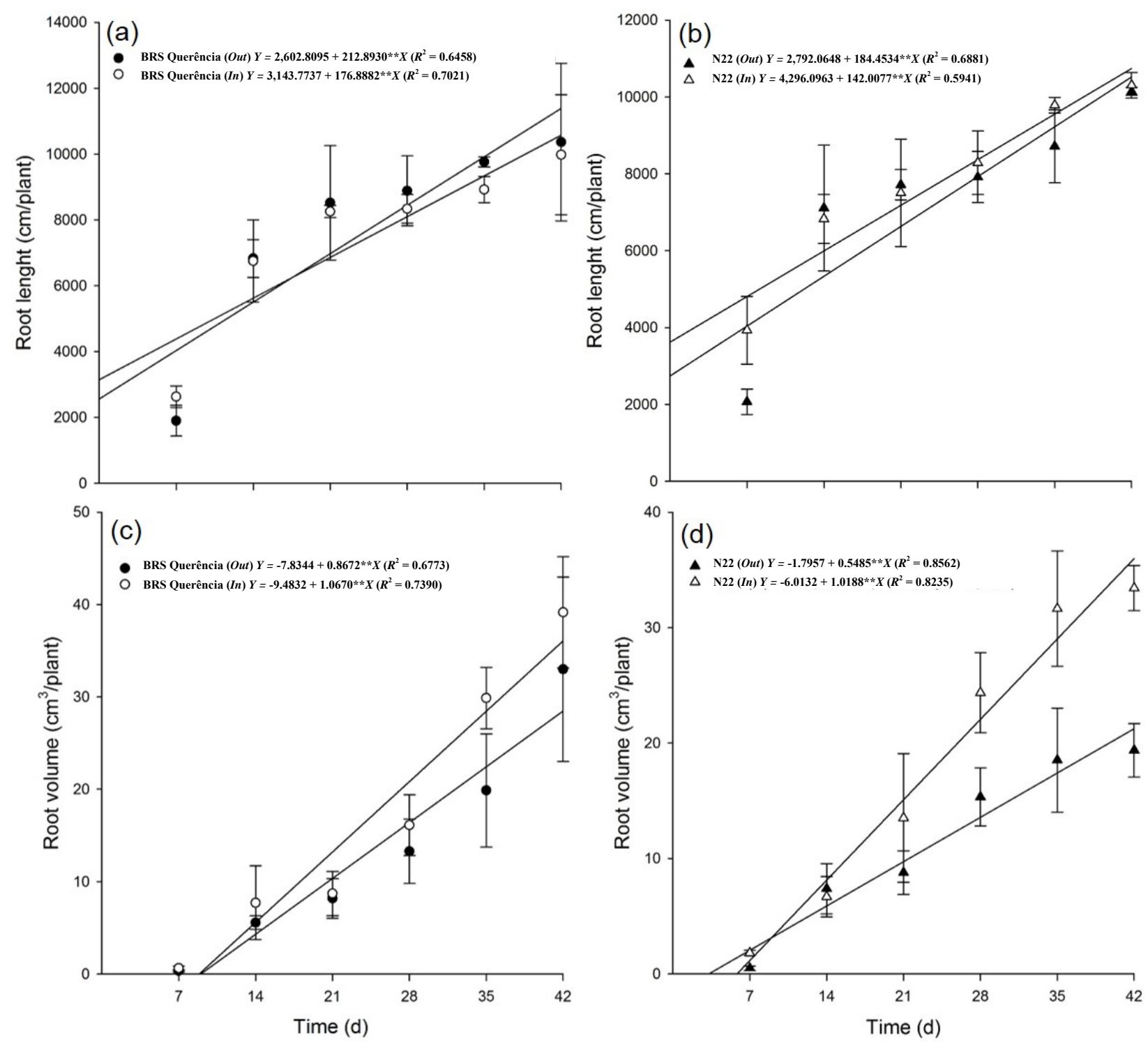

Fig. 5 Length and volume of two rice roots in response to above-optimal temperature (BRS Querência (a and c) and N22 (b and d)).

"In"-plants growing in rhizotrons under plastic protection; "Out"- plants growing in rhizotrons under environmental temperature conditions (a and c).

Values represent the mean $\pm \operatorname{SE}(n=3)$.

might be related to driving the energy flux of the photosystems through photorespiration as a mechanism to dissipate part of the energy produced by the photochemical process under normal environmental conditions [34], when temperature increases in In conditions, the energy flux is driven to photosynthesis and may decrease photorespiration.

In general, the response to the capacity of electron transport to elevated temperature changes among the species [32]. Besides, plants under heat stress can adjust the metabolism, presenting strategies to maintain the structures of the photosystems, which in turn lead to a reduction in the ETR under stress [35]. Photosystems are also very sensitive to temperature variations due to its position within the membrane of the thylakoids [36], and a few degrees above in the temperature can increase the membrane fluidity, leading to disorganization of the photosystems apparatus 

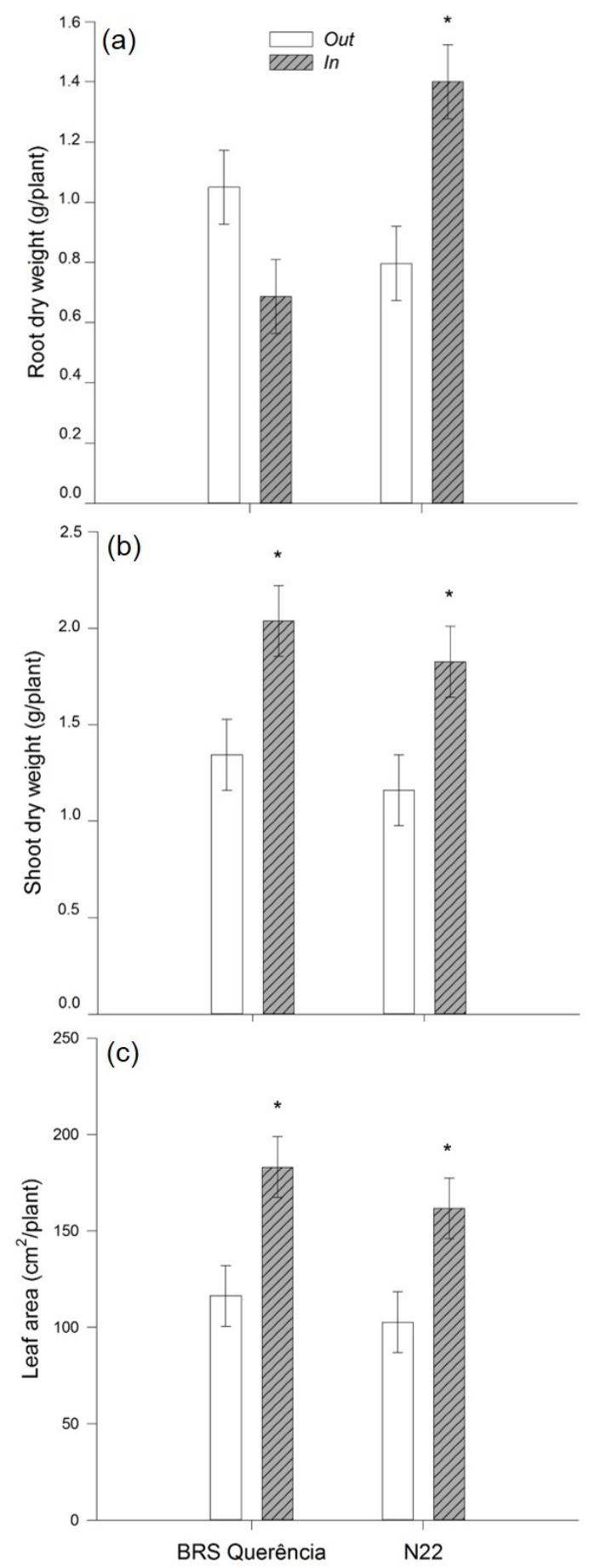

Fig. $6 R D W(a), S D W(b)$ and $L A$ (c) of two irrigated rice genotypes in response to above-optimal temperature (BRS Querência and N22).

"In"-plants growing in rhizotrons under plastic protection; "Out"-plants growing in rhizotrons under environmental temperature conditions.

An asterisk $(*)$ indicates significant difference by Student's test $(p \leq 0.05)$ between treatments (In and Out) for each genotype. Values represent the mean $\pm \operatorname{SE}(n=3)$.
[37]. In this sense, Leakey et al. [28] showed that leaf temperature above $34{ }^{\circ} \mathrm{C}$ can slower the electron transport capacity, however, driving more efficiently the energy (ATP and NADPH) to photosynthetic processes by increasing $\mathrm{CO}_{2}$ assimilation and may reduce photorespiration.

\subsection{Morphometric Responses of Rice to Above-Optimal Temperature}

The root length and volume were shown in Fig. 5. In both genotypes, the root length was not affected by increasing temperature during with the time course of the experiment (Figs. 5a and 5b). In relation to root volume, there was an increase in both genotypes in the condition In, with greater increase in N22, which ranged about $70 \%$ over the plants in Out (Figs. $5 \mathrm{c}$ and $5 d)$.

$R D W$ increased consistently about twice upon elevated temperature (In) compared to control (Out) in N22, while no changes occur in the genotype sensitive BRS Querência (Fig. 6a). In relation to $S D W$ (Fig. 6b) and $L A$ (Fig. 6c), both genotypes, BRS Querência and N22 showed a greater increase (about twice) upon elevated temperature (In) compared to the control (Out).

According to Arai-Sanoh et al. [38], environments with elevated air temperature lead to an increase in the soil temperature that can affect the root growth of plants. The rise in soil temperature has been reported to affect negatively when above $30{ }^{\circ} \mathrm{C}$, the temperature limit for sensitive rice crops to develop the root system. As showed by the sensitive genotype, BRS Querência, there was no significant difference in $R D W$ though slight decrease occurred, characterizing that the soil temperature reached the maximum to keep the growth of roots without several damages. Different from plants of BRS Querência, in N22, there was an increase in root growth in plants under In conditions compared with plants in Out (Fig. 6a). These differences may be related to the increased photosynthetic rate and carbohydrates partitioning 


\section{Above-Optimum Temperature-Induced Differential Photosynthetic and Roots Morphometric Responses in Two Contrasting Rice Genotypes}

between root and shoot in N22 [39], while there was an increase in the respiration rate in BRS Querência [40].

LA of plants is strongly affected by temperature, radiation, shading, photoperiod, air moisture, water availability and mineral nutrients [41, 42]. As found in the experiment, Hay and Wilson [43] and McMaster et al. [44], showed that increases in the temperature close to the root zone affect the growth and development of leaves, besides several physiological processes in rice plants. In general, the greater response of N22 to above-optimal temperature may be related to a thermotolerance of this genotype over BRS Querência that showed to be more sensitive to the effects of elevated temperature.

\section{Conclusions}

Above-optimal temperature affects more negatively the photosynthetic and morphometric responses of BRS Querência genotype in comparison to N22. In general, N22 genotype showed greater response to above-optimal temperature due to its intrinsic thermotolerance traits over BRS Querência. Thus, N22 appears as a potential donor of heat tolerance genes aiming to obtain new cultivar to face current global warming.

\section{Acknowledgments}

Financial support was provided by $\mathrm{CNPq}$ via CHAMADA UNIVERSAL-MCTI/CNPq $\quad \mathrm{N}^{\circ}$ 14/2014 and Brazilian Agricultural Research Corporation_-Embrapa via Macro II Edital.

\section{References}

[1] Seck, P. A., Diagne, A., Mohanty, S., and Wopereis, M. C. S. 2012. "Crops that Feed the World 7: Rice." Food Security 4 (1): 7-24.

[2] United Nations (UN). 2017. "World Population Prospects." Accessed June 14, 2017. http://www.un.org/en/documents/index.html.

[3] Food and Agriculture Organization of the United Nations (FAO). 2017. "How to Feed the World in 2050." Accessed July 20, 2017. http://www.fao.org/publications.
[4] Peng, S., Huang, J., Sheehy, J. E., Laza, R. C., Visperas, R. M., Zhong, X., Centeno, C. S., Khush, G. S., and Cassman, K. G. 2004. "Rice Yields Decline with Higher Night Temperature from Global Warming." In Proceedings of the National Academy of Sciences of the United States of America 101 (27): 9971-5.

[5] Hatfield, J. L., Boote, K. J., Kimball, B. A., Ziska, L. H., Izaurralde, R. C., Ort, D., Thomson, A. M., and Wolfe, D. W. 2011. "Climate Impacts on Agriculture: Implications for Crop Production.” Agronomy Journal 103 (2): 351-70.

[6] Intergovernmental Panel Climate Change (IPCC). 2014. "Climate Change 2014 Impacts, Adaptation, and Vulnerability Part A: Global and Sectoral Aspects." Accessed May 16, 2017. http://www.ipcc.ch/pdf/ assessment-report/ar5/wg2/WGIIAR5-PartA_FINAL.pdf.

[7] Pinto, H. S., Assad, E. D., Junior, J. Z., Evangelista, S. R. M., Otavian, A. F., Ávila, A. M. H., Evangelista, B., Marin, F. R., Junior, C. M., Pellegrino, G. Q., Coltri, P. P., and Coral, G. 2008. Global Warming and the New Geography of Agricultural Production in Brazil. São Paulo: Embrapa.

[8] Companhia Nacional de Abastecimento (CONAB). 2016. "Follow-Up of the Brazilian Grain Harvest-Twelfth Survey-2015/2016." Accessed February 13, 2017. http://www.conab.gov.br.

[9] Scafaro, A. P., Haynes, P. A., and Atwell, B. J. 2010. "Physiological and Molecular Changes in Oryza meridionalis Ng., a Heat-Tolerant Species of Wild Rice." Journal of Experimental Botany 61 (1): 191-202.

[10] Brito, G. G., Fagundes, P. R. R., Teló, G. M., Abreu, A. G., De Magalhães Júnior, A. M., Franco, D. F., Andres, A., Parfitt, J. M. B., Kuhn, R., and Petrin, J. A. 2016. "Impact of Supraoptimal Temperatures on Physiology and Yield in Rice Field." Journal of Agricultural Science 8 (2): 27-37.

[11] Yoshida, S. 1981. Fundamentals of Rice Crop Science. Los Baños: IRRI.

[12] Hatfield, J. L., and Prueger, J. H. 2015. "Temperature Extremes: Effect on Plant Growth and Development." Weather and Climate Extremes 10 (A): 4-10.

[13] Hüve, K., Bichele, I., Rasulov, B., and Niinemets, Ü. 2011. "When It Is Too Hot for Photosynthesis: Heat-Induced Instability of Photosynthesis in Relation to Respiratory Burst, Cell Permeability Changes and $\mathrm{H}_{2} \mathrm{O}_{2}$ Formation." Plant, Cell and Environment 34 (1): 113-26.

[14] Matsushima, S., Tanaka, T., and Hoshino, T. 1964. "Analysis of Yield-Determining Process and Its Application to Yield-Prediction and Culture Improvement of Lowland Rice: LXX. Combined Effect of Air-Temperatures and Water-Temperatures at Different Stages of Growth on the Grain Yield and Its Components of Lowland Rice.” Japanese Journal of Crop Science 33 
(1): 53-8.

[15] Singh, S. 2001. "Growth, Yield and Biochemical Response of Rice Genotype to Low Light and High Temperature-Humidity Stress." Oryza 37 (1): 35-8.

[16] Luo, Q. 2011. "Temperature Thresholds and Crop Production: A Review." Climatic Change 109 (3-4): 583-98.

[17] Reynolds, L. K., DuBois, K., Abbott, J. M., Williams, S. L., and Stachowicz, J. J. 2016. "Response of a Habitat-Forming Marine Plant to a Simulated Warming Event Is Delayed, Genotype Specific, and Varies with Phenology." PLoS One 11 (6): 1-16.

[18] Baker, J. T., Boote, K. J., and Allen, L. H. Jr. 1995. "Potential Climate Change Effects on Rice: Carbon Dioxide and Temperature." In Climate Change and Agriculture: Analysis of Potential International Impacts, edited by Rosenzweig, C., Jones, J. W., and Allen, L. H. Jr. Madison: ASA Spec. Pub., 31-47.

[19] Cheng, W., Sakai, H., Yagi, K., and Hasegawa, T. 2010. "Combined Effects of Elevated $\mathrm{CO}_{2}$ and High Night Temperature on Carbon Assimilation, Nitrogen Absorption, and the Allocations of $\mathrm{C}$ and $\mathrm{N}$ by Rice (Oryza sativa L.)." Agricultural and Forest Meteorology 150 (9): 1174-81.

[20] Prasad, P. V. V., Boote, K. J., Allen, L. H. Jr., and Sheehy, J. E. 2006. "Species, Ecotype and Cultivar Differences in Spikelet Fertility and Harvest Index of Rice in Response to High Temperature Stress." Field Crops Research 95 (2-3): 398-411.

[21] Ntanos, D. A., and Koutroubas, S. D. 2002. "Dry Matter and $\mathrm{N}$ Accumulation and Translocation for Indica and Japonica Rice under Mediterranean Conditions.” Field Crops Research 74 (1): 93-101.

[22] Jagadish, S. V. K., Muthurajan, R., Oane, R., Wheeler, T. R., Heuer, S., Bennett, J., and Craufurd, P. Q. 2010. "Physiological and Proteomic Approaches to Address Heat Tolerance during Anthesis in Rice." Journal of Experimental Botany 61 (1): 143-56.

[23] Berry, J. A., and Björkman, O. 1980. "Photosynthetic Response and Adaptation to Temperature in Higher Plants." Annual Review of Plant Physiology 31 (1): 491-543.

[24] Schrader, S. M., Wise, R. R., Wacholtz, W. F., Ort, D. R., and Sharkey, T. D. 2004. "Thylakoid Membrane Responses to Moderately High Leaf Temperature in Pima Cotton.” Plant Cell and Environment 27 (6): 725-35.

[25] Kim, K., and Portis, A. R. Jr. 2005. "Temperature Dependence of Photosynthesis in Arabidopsis Plants with Modifications in RuBisCO Activase and Membrane Fluidity." Plant and Cell Physiology 46 (3): 522-30.

[26] Kubien, D. S., and Sage, R. F. 2008. "The Temperature Response of Photosynthesis in Tobacco with Reduced
Amounts of RuBisCO." Plant, Cell \& Environment 31 (4): 407-18.

[27] Zhang, R., Cruz, J. A., Kramer, D. M., Magallanes-Lundback, M. E., DellaPenna, D., and Sharkey, T. D. 2009. "Moderate Heat Stress Reduces the $\mathrm{pH}$ Component of the Transthylakoid Proton Motive Force in Light-Adapted, Intact Tobacco Leaves." Plant, Cell \& Environment 32 (11): 1538-47.

[28] Leakey, A. D. B., Press, M. C., Scholes, J. D., and Watling, J. R. 2002. "Relative Enhancement of Photosynthesis and Growth at Elevated $\mathrm{CO}_{2}$ Is Greater under Sunflecks than Uniform Irradiance in a Tropical Rain Forest Tree Seedling." Plant Cell and Environment 25 (12): 1701-14.

[29] Pons, T. L., and Welschen, R. A. M. 2003. "Midday Depression of Net Photosynthesis in the Tropical Rainforest Tree Eperua grandiflora: Contributions of Stomatal and Internal Conductances, Respiration and RuBisCO Functioning.” Tree Physiology 23 (14): 937-47.

[30] Restrepo-Diaz, H., and Garces-Varon, G. 2013. "Response of Rice Plants to Heat Stress during Initiation of Panicle Primordia or Grain-Filling Phases.” Journal of Stress Physiology \& Biochemistry 9 (3): 318-25.

[31] Tribuzy, E. S. 2005. "Foliar Temperature Variation of Canopy and Its Effect on Net Assimilation Rate in Central Amazonia." Ph.D. thesis, Escola Superior de Agricultura Luiz de Queiroz, 84.

[32] Medlyn, B. E., Badeck, F. W., De Pury, D. G. G., Barton, C. V. M., Broadmeadow, M., Ceulemans, R., De Angelis, P., Forstreuter, M., Jach, M. E., Kellomaki, S., Laitat, E., Marek, M., Philippot, S., Rey, A., Strassemeyer, J., Laitinen, K., Liozon, R., Portier, B., Roberntz, P., Wang, K., and Jarvis, P. G. 1999. "Effects of Elevated $\left(\mathrm{CO}_{2}\right)$ on Photosynthesis in European Forest Species: A Meta-analysis of Model Parameters." Plant Cell and Environment 22 (12): 1475-95.

[33] Oberhuber, W., Dai, Z. Y., and Edwards, G. E. 1993. "Light Dependence of Quantum Yields of Photosystem II and $\mathrm{CO}_{2}$ Fixation in $\mathrm{C}_{3}$ and $\mathrm{C}_{4}$ Plants." Photosynthetic Research 35 (3): 265-74.

[34] Yamasaki, T., Yamakawa, T., Yamane, Y., Koike, H., Satoh, K., and Katoh, S. 2002. "Temperature Acclimation of Photosynthesis and Related Changes in Photosystem II Electron Transport in Winter Wheat." Plant Physiology 128 (3): 1087-97.

[35] Inoue, N., Taira, Y., Emi, T., Yamane, Y., Kshino, Y., Koike, H., and Satoh, K. 2001. "Acclimation to the Growth Temperature and the High-Temperature Effects on Photosystem II and Plasma Membranes in a Mesophilic Cyanobacterium, Synechocystis sp. PCC6803." Plant Cell Physiology 42 (10): 1140-8.

[36] Badretdinov, D. Z., Baranova, E. A., Kuznetsova, S. A., 


\section{Above-Optimum Temperature-Induced Differential Photosynthetic and Roots Morphometric Responses in Two Contrasting Rice Genotypes}

Tuleshova, A. A., and Kukushkin, A. K. 2002. "Experimental and Theoretical Study of Temperature Dependence of Steady-State Parameters of Delayed Luminescence Induction in Leaves of Higher Plants." Biofizika 47 (5): 872-7.

[37] Niinemets, U., Oja, V., and Kull, O. 1999. "Shape of Leaf Photosynthetic Electron Transport versus Temperature Response Curve Is Not Constant along Canopy Light Gradients in Temperate Deciduous Trees." Plant Cell and Environment 22 (12): 1497-513.

[38] Arai-Sanoh, Y., Ishimaru, T., Ohsumi, A., and Kondo, M. 2010. "Effects of Soil Temperature on Growth and Root Function in Rice." Plant Production Science 13 (3): 235-42.

[39] Xu, Q., and Huang, B. 2000. "Effects of Differential Air and Soil Temperature on Carbohydrate Metabolism in Creeping Bentgrass." Crop Science 40 (5): 1368-74.

[40] Du, Y. C., and Tachibana, S. 1994. "Photosynthesis, Photosynthetic Translocation and Metabolism in Cucumber Roots Held at Supraoptimal Temperature." Journal of the Japanese Society for Horticultural Science
63 (2): 401-8.

[41] Tardieu, F., Reymond, M., Muller, B., Granier, C., Simonneau, T., Sadok, W., and Welcker, C. 2005. "Linking Physiological and Genetic Analyses of the Control of Leaf Growth under Changing Environmental Conditions." Australian Journal of Agricultural Research 56 (9): 937-46.

[42] Schurr, U., Walter, A., and Rascher, U. 2006. "Functional Dynamics of Plant Growth and Photosynthesis-From Steady-State to Dynamics-From Homogeneity to Heterogeneity." Plant, Cell and Environment 29 (3): 340-52.

[43] Hay, R. K. M., and Wilson, G. T. 1982. "Leaf Appearance and Extension in Field-Grown Winter Wheat Plants: The Importance of Soil Temperature during Vegetative Growth.” Journal of Agricultural Science 99 (2): 403-10.

[44] McMaster, G. S., Wilhelm, W. W., Palic, D. B., Porter, J. R., and Jamieson, P. D. 2003. "Spring Wheat Leaf Appearance and Temperature: Extending the Paradigm?" Annals of Botany 91 (6): 697-705. 